The author holds a PhD in English Linguistics from Universidad de Sevilla. He currently is Associate courses on pragmatics, discourse analysis, translation and English for the tourism industry. He is co-editor-inchief of the book series "Advances in Pragmatics and Discourse Analysis" (CSP) and has authored various of instructional pragmatics is "An integrative proposa to teach the pragmatics of phatic communion in ESL classes", published in Intercultural Pragmatics. The current paper is supported by the research project La formación de la conciencia figurativa en la etap de Educación Primaria: el humor y la fraseologia Investigación of the Spanish Ministerio de Econol dí Industria y Competitividad. https://0000-0003-2908-7261.

E-mail: mpadillacruz@us.e

Recebido em: 25/10/2019 Aprovado em: 28/10/2019.

Endereço:

Universidade de Sevilla

C/ PALOS DE LAFRONTERA, SIN

C.P: 41004

Sevilla

\section{Dealing with jokes in the ESL class: a pedagogical proposal centred on comprehension}

\author{
Lidando com piadas na aula de ESL: uma proposta pedagógica centrada na compreensão
}

Manuel Padilla Cruz ${ }^{1}$

Departamento de Filología Inglesa (Lengua Inglesa), Facultad de Filología. Universidad de Sevilla, Spain

\section{ABSTRACT}

This paper makes a pedagogical proposal to delve into jokes in the ESL classroom and sensitise learners to their complexity. It consists of five instructional phases and is based, on the one hand, on another proposal to teach the pragmatics of speech acts in an L2. On the other hand, this proposal relies on a relevance-theoretic classification of jokes made on the basis of the various linguistic, cultural and cognitive factors that humorists exploit in their production. Since it only centres on how different types of jokes can be distinguished and what their correct comprehension involves, it has a cognitive orientation and does not address issues connected with joke production. The proposal is devised for ESL students with an advanced level of English and ultimately seeks to develop their metalinguistic, meta-cultural and metacognitive abilities as a way of enabling them to grasp the humorousness of funny texts, appraise them and react to them in an appropriate way.

KEYWORDS: Joke Types; Humour; Instructional Pragmatics; Pedagogical Proposal; Metapragmatic Awareness.

\section{RESUMO}

Este artigo traz uma proposta pedagógica para aprofundar as piadas na sala de aula de ESL (Inglês como língua estrangeira, na tradução para a língua portuguesa) e sensibilizar os alunos a respeito de sua complexidade. Ela consiste em cinco fases instrucionais que, por um lado, baseia-se em outra proposta de ensino da pragmática dos atos de fala em uma L2 e, por outro lado, baseia-se em uma classificação teórica da relevância das piadas feitas com base nos vários fatores linguísticos, culturais e cognitivos que os humoristas exploram em sua produção. Como a proposta se concentra apenas em como os diferentes tipos de piadas podem ser distinguidos e em qual a correta compreensão envolvida, ela tem uma orientação cognitiva e não aborda questões relacionadas à produção da piada. A proposta é elaborada para estudantes de ESL com um nível avançado de inglês e, por conseguinte, busca desenvolver suas habilidades metalinguísticas, meta-culturais e metacognitivas como uma maneira de permitir-lhes compreender o humor de textos engraçados, avaliá-los e reagir a eles apropriadamente.

PALAVRAS-CHAVE: Tipologia de piadas; Humor; Pragmática Instrucional; Proposta Pedagógica; Consciência Metapragmática. 


\section{Introduction}

A

quick look at the syllabi of several ESL courses and the tables of contents of many of the available teaching materials for different proficiency levels suffices to detect that humour, far from being underrepresented, is not present at all in most of them. At the very best, inspection reveals the inclusion of some jokes or comic vignettes every now and then in coursebooks and workbooks, or of brief excerpts of informal funny conversations in supportive audiovisual materials. Nor do materials for instructors contain helpful guidelines to deal with its intricacies or to take advantage of it while addressing other topics. Undeniably, pedagogical materials give prominence to the four traditional skills on which L2 mastery depends and tend to focus on linguistic areas like vocabulary, morphology, syntax, discourse and pragmatics, and, in the case of those for specific purposes, professional skills. As regards L2 discourse and pragmatics, attention is chiefly paid to production; when it comes to comprehension, what teachers normally find is advice about how to cope with unusual, misleading, jargon-specific, homophonous, homonymous or polysemous lexical items, false friends, complex syntactic structures, some figures of speech or possible misunderstandings, to name but some examples.

This paper purports to offer a pedagogical proposal to deal not with humour as a whole in the ESL classroom -which might be difficult owing to its manifold manifestations and almost impossible due to scarce time availability, among other things- but with just one of its manifestations: namely, jokes. It is not an all-encompassing proposal, as it will not include suggestions to tackle joke-telling or issues connected with the production of jokes, such as prosody, voice shifts, pantomime, gestures, facial expressions or other cues to indicate humorous intent (NORRICK, 2004). Those are rather complex issues which are, furthermore, contingent on personal abilities and factors, such as having a sense of humour and being gifted with some required comicality, funniness or flair (DYNEL, 2007); being in the adequate mood and/or experiencing certain inner states; having a close, amicable or intimate relationship with the potential target audience (YUS RAMOS, 2016); endorsing specific beliefs and values, and even ethnicity, gender and/or geographical provenance (RITCHIE, 2004). Additionally, joke production is conditioned by external factors, such as time availability, task-focus, group size and composition, and even factors connected with the jokes themselves, such as their topic(s) (YUS RAMOS, 2016).

In line with Szirmai (2012) and Bell (2017), this proposal will only focus on cognitive issues pertaining to jokes: namely, the linguistic, cultural and cognitive elements intervening in their production, as well as their manipulation by humorists with a view to generating a(n expected) humorous reaction. Hence, it aims to serve as a useful tool that may be implemented by instructors in order to help ESL learners develop the necessary metalinguistic, metacultural and metacognitive skills facilitating their appraisal of and adequate reaction to this form of humour by understanding how various types of jokes work, where their humour resides and why some of them might turn out socially risky or hazardous (SZIRMAI, 2012, p. 197; BELL, 2017, p. 448). All in all, this proposal attempts to contribute to improving ESL learners' metapragmatic awareness of the complexity of joke production and comprehension (SHARWOOD-SMITH, 1981; THOMAS, 1983; HOUSE, 1990; OLSHTAIN, COHEN, 1990, 1991; KASPER, ROSE, 2002), which is essential to making them more successful listeners and sensitive to the intricacies of a type of humorous discourse that very often poses many challenges to them (BELL, 2017, p. 448).

The instructional proposal presented here is inspired by another made some years ago for teaching pragmatic aspects of verbal actions: the socalled 6Rs approach after the names given to the distinct phases it comprises (MARTÍNEZ FLOR, USÓ JUAN, 2006). However, their number is adapted so as to fit the current target of instruction and orientation. Its recipients are not intended to be ESL learners with limited proficiency level, but those with an advanced level at least, or, using the labels of the Common European Framework of Reference for Languages, $\mathrm{C} 1$ or $\mathrm{C} 2$ students. In fact, it is at those levels that their command of grammatical and many pragmatic aspects of the target language, as well as their listening and reading skills, are gaining more sophistication or have already done so. But before presenting it, it is advisable to consider why humour in general, and jokes in particular, should be put in the spotlight in ESL instruction, and to discuss how jokes may be approached. 


\section{Why is it worthwhile dealing with jokes in the ESL class?}

With its manifold manifestations, humour is an incredibly complex phenomenon that finds its way in many social situations (NORRICK, 1993; NORRICK, CHIARO, 2009). Leaving aside forms like comics, cartoons, signs or memes, which in some cases combine a visual element with a textual one, verbal manifestations encompass banter and jocular teasing (SLUGOSKI, TURNBELL, 1988; DYNEL, 2008), puns or wordplays taking advantage of homonymy, polysemy, homophony or paronymy (BUCARIA, 2004; SOLSKA, 2012a, 2012b), and conversational humour. This consists of conversational episodes that include utterances or narrations that unexpectedly turn out hilarious, or decidedly funny ones, such as witticisms, anecdotes, similes and, evidently, canned and non-canned jokes (NORRICK, 2010). Despite their low relevance in informational terms, these trigger laughter, amusement, enjoyment or pleasure, which certainly compensate for the cognitive effort that they demand (YUS RAMOS, 2016).

Humour in general, and jokes in particular, may facilitate the achievement of thorny interactive goals, like voicing controversial opinions, disagreeing, making requests or ordering, to name but some (ATTARDO, 2002), and/or mitigate conflicts (NORRICK, SPITZ, 2008). Indeed, they count as one of the positive-politeness strategies identified by Brown and Levinson (1987) because of their function as a self-protecting device helping interlocutors cope with situations and problems liable to threaten either the speakers or the hearers' positive or negative face (HAY, 2000; DYNEL, 2007). Jokes also foster solidarity because of the information that they reveal about their tellers, and because they suggest points in common, highlight and celebrate shared experiences, interests, values or viewpoints, and delineate groups through references to accepted and agreed-upon standards. In friendly gatherings, moreover, they contribute to the construction of a play frame that enables interlocutors to show collaboration and like-mindedness (YUS RAMOS, 2016, p. 324).

It should be clear at this point that while it is one thing to deal with humour itself, it is quite another to use it in class. Although many teachers avoid it because of their personality, lack of skills or syllabus-orientedness (ZIYAEEMEHR, KUMAR, ABDULLAH, 2011), many others, owing to its important psychological and social effects, purposefully wield it as a pedagogical tool through highly idiosyncratic discursive tactics (REDDINGTON, WARING, 2015).
In addition to enhancing motivation, engagement, interaction, attention, interest and content retention, and to reducing anxiety (POWELL, ANDRESEN, 1985; MEDGYES, 2002; LOVORN, 2015), humour enables students to create different and wider classroom identities (SHARDAKOVA, 2013), and prompts them to perform linguistic actions in more innovative and sophisticated ways than those frequently found in L2 classes (POMERANTZ, BELL, 2011). Teacher-generated humour has certainly been proved to foster learning enjoyment (COOK, 2000; ALDRICH, 2015) and to sometimes be an effective means to assert roles, mediate in the class and manage disruptive behaviour (POWELL, ANDRESEN, 1985; SMILEY, ANTÓN, 2012). It may revitalize classes and make learning a memorable experience (DERAKHSHAN, 2016), although teachers must always be sensitive to group and individual singularities, cultural idiosyncrasies and cross-cultural differences (OLAJOKE, 2013). In turn, student-generated humour helps learners to oppose or resist monotonous, tiresome or (excessively) demanding instructional practices. Therefore, inclass humour often becomes a safe house (POMERANTZ, BELL, 2011).

In the realm of L2 instruction, jokes are particularly interesting for linguistic, cultural and cognitive reasons. Firstly, they exploit the pragmatic ambivalence of specific lexical items, phrases or full sentences, which are amenable to differing interpretations. The setting of the joke -also technically labelled the multiple-graded interpretation part (YUS RAMOS, 2003)- guides the audience to an initial interpretation that appeals to them as plausible and reasonable because it demands little cognitive effort and apparently yields a satisfactory amount of cognitive benefits (JODŁOWIEC, 1991; CURCÓ, 1995, 1997; YUS RAMOS, 2003). That salient interpretation (GIORA, 1999) then needs to be abandoned as a result of the occurrence of an incongruous element (SULS, 1977; RITCHIE, 2004), which challenges the audience, arises their curiosity and triggers the need to solve it (YUS RAMOS, 2016, p. 307) ${ }^{2}$. Solving ambiguities may make learners aware of the multi-functionality of words and textual stretches, and contribute to their vocabulary, syntax, pronunciation, spelling, reading and writing skills.

Secondly, jokes rely on the activation or strengthening of encyclopaedic information connected with specific concepts, make-sense frames or stereotypical

See Forabosco (2008) for comments on the plausibility of the incongruity-resolution model to account for humour and, more specifically, jokes. 
scenarios of situations and events, and relatively stable cultural information pertaining to cultural and social stereotypes, for instance regarding gender roles, ethnic features or geographical provenance. Although these endow texts and interpretations with sense, reasonableness and plausibility, the introduction of the incongruous element incites the rejection of an initially activated frame or item of encyclopaedic information, and instigates the search for alternative ones (NORRICK, 1986; YUS RAMOS, 2016). To aid in advance ESL learners' development, frame analysis and discussion of cultural information involved in the interpretation of jokes could help L2 learners realise diverse conceptualisations of reality and sensitise them to different cultural values, norms and practices.

However, if there is something that makes jokes especially suitable for the L2 class, it is their cognitive underpinnings (BELL, 2017). Their production greatly depends on mindreading abilities (APPERLY, 2010). Humorists must anticipate (very) likely, costless, easily accessible interpretations of specific words, phrases or sentences, and the frame(s) or item(s) of encyclopaedic information that the audience might activate or have access to. In other words, they must predict the interpretative route that they will follow. But the interpretation of jokes is not only contingent on such mental abilities, but also on vigilant attitudes (PADILLA CRUZ, 2012, 2014, 2015a). Rejection of an initially activated frame, accessed cultural information and/or a first interpretation are only possible if the audience notice the incongruous element, check the implausibility of any of those elements, and realise that the humorist has, in a manner of speaking, deceived or misguided them (RASKIN, 1985; ATTARDO, RASKIN, 1991). This requires that the audience be critically alert to the reliability or helpfulness of the accessed cultural information and to the beliefs stored in the activated frames, as well as to the plausibility and correctness of the constructed interpretation. To put it differently, the audience needs to be epistemically vigilant (MASCARO, SPERBER, 2009; SPERBER et al., 2010) and hermeneutically vigilant (PADILLA CRUZ, 2014, 2015a, 2016, 2017).

Detection of a useless frame, inadequate cultural information and/or an inappropriate interpretation causes the audience to be willing to invest the additional cognitive effort necessary to re-process the text of the joke through the search for alternatives for any of them. This involves a shift from the processing strategy known as naïve optimism (SPERBER, 1994), as a result of which hearers or readers tend to regard relatively effortless, reasonable and effect-yielding interpretations as intended, to another known as sophisticated understanding (SPERBER, 1994), which enables them to notice an attempt at deception, to wonder which other interpretation a speaker or writer prevented them from reaching and to undertake an active search for it (PADILLA CRUZ, 2012, 2015a). Introducing L2 learners to the cognitive side of jokes may facilitate understanding of the tasks that the mind performs and the steps that it takes while processing them, and sensitise them to the importance of being critical about the mental frames that they activate, the pieces of information that they rely on and the rightness of their interpretations.

\section{How should jokes be tackled?}

If jokes are to be the focus of instruction, it is important to emphasise that not all of them achieve their intended humorous effects in the same manner. Reliance on diverse criteria have given rise to several classifications thereof. For example, Suls $(1977,1983)$ and Ritchie $(2004,2006)$ take into account the nature of the incongruous element, how it is introduced, its placement within the text, whether the arising incongruity is resolved and, if so, how. Yus Ramos (2003) differentiates between them depending on the transparency of the humorist's intentionality or their degree of integration in conversations, with canned jokes being signaled through various means. In turn, Dynel (2012) sorts them into three categories on the basis of their reliance on any of three mechanisms: garden-path, red-light and crossroads. However, individuating jokes through the linguistic, cultural and cognitive factors that jokers exploit when contriving them would be more realistic, naturalistic and illustrative, as long as L2 learners could become aware of the distinct mental operations needed for their interpretation, their possible outputs and the range of commonsensical and/or cultural information upon which their jocularity is contingent (YUS RAMOS, 2016, p. 115).

Reacting against those taxonomies, and refining two of his own previous ones (YUS RAMOS, 2008, 2013a), Yus Ramos (2016) considers three parametres involved in joke-construction: the make-sense frame(s) that jokes activate, the cultural information shared by the community to which the audience belongs, and the steps that the mind takes and the computations that it makes while constructing an interpretation. These parametres are purposefully exploited by humorists, jointly or separately, and their combination yields the following seven types of jokes: 
a) [Utterance interpretation] jokes, which play with the cancelation of an initial effortless and seemingly plausible interpretation owing to an inadequate parsing of syntactic constituents (1), wrong disambiguation of the sense of, for example, polysemous (2) or homophonous words (3), incorrect assignment of reference to some expressions like anaphoric pronouns (4), inappropriate lexical adjustment of words metaphorically used (5) or misattribution of intentions, feelings or emotions to some character in the joke (6) (YUS RAMOS, 2016, p. 133-138):

(2) An English teacher wrote these words on the whiteboard: "woman without her man is nothing". The teacher then asked the students to punctuate the words correctly. The men wrote: "Woman, without her man, is nothing". The women wrote: "Woman! Without her, man is nothing".

(3) Mr. Isar was attending his friend's wife's funeral. "It must be hard to lose a wife", remarked Mr. Isar. "Almost impossible", remarked his friend (from YUS RAMOS, 2016, p. 134) ['hard' = 'sad' vs. 'difficult']

(4) Question: Why did the bald man paint rabbits on his head? Answer: Because from a distance they looked like hares! ['hares' vs. 'hairs']

(5) Don't kill yourself in the garden. Let us do it for you. (from YUS RAMOS, 2016, p. 134) ['it' = 'overwork' vs. 'kill you']

(6) A little boy says: "Daddy, how was I born?" Dad says: "Ah, my son. I guess one day you will need to find out anyway! Well, you see, your mom and I first got together in a chat room on MSN. Then I set up a date via e-mail with your mom and we met at a cyber-cafe. We sneaked into a secluded room, where your mother agreed to a download from my hard drive. As soon as I was ready to upload, we discovered that neither one of us had used a firewall, and since it was too late to hit the delete button, nine months later a blessed popup appeared and said: You've got male!"

(7) A guy found a sheep and showed him to a policeman. The policeman said, "Take that sheep to the zoo, now". Next day the po- liceman sees the man with the sheep again. The policeman stops the guy and says, "What on earth are you doing with that sheep?" The guy says, "What is there to do? Yesterday I took him to the zoo and now I'm taking him to the movies". [Did the policeman want the guy to take the sheep to the zoo and leave it there or to take it to the zoo so that it could have some fun?]

b) [Make-sense] jokes, which are based on the invalidation of an initially activated frame, as in the following example (YUS RAMOS, 2016, p. 132):

(7) One night, a father passed by his son's room and heard his son praying: "God bless mommy, daddy, and grandma. Ta, ta, grandpa". The father didn't quite know what this meant, but was glad his son was praying. The next morning, they found grandpa dead on the floor of a heart attack. The father reassured himself that it was just a coincidence, but was still a bit spooked. The next night, he heard his son praying again: "God bless mommy and daddy. Ta, ta, grandma". The father was worried, but decided to wait until morning. Sure enough, the next morning grandma was on the floor, dead of a heart attack. Really scared now, the father decided to wait outside his son's door the next night. And sure enough, the boy started to pray: "God bless mommy. Ta, ta, daddy". Now the father was crapping his pants. He stayed up all night, and went to the doctor's early the next day to make sure his health was fine. When he finally came home, his wife was waiting on the porch. She said, "Thank God you're here! We could really use your help! We found milkman dead on our porch this morning!"

c) [Cultural frame] jokes, which take advantage of information about social stereotypes connected with gender roles, professions, nationalities, ethnicities, etc., which are liable to be strengthened or challenged (YUS RAMOS, 2016, p. 132-133). An example could be the following joke:

(8) Matt's dad picked him up from school to take him to a dental appointment. Knowing the parts for the school play were supposed to be posted today, he asked his son if he had got one. Matt enthusiastically announced that he had. "I play a man who's been married 
for twenty years". "That's great, son. Keep up the good work and before you know it they'll be giving you a speaking part". (from YUS RAMOS, 2016, p. 133)

d) [Make-sense frame]+[utterance interpretation] jokes, in which the frame in question biases a seemingly plausible interpretation that needs to be rejected at the end and replaced with another one (YUS RAMOS, 3016, p. 128-131). A case in point would be the following joke:

(9) As a senior citizen was driving down the freeway, his cell phone rang. Answering, he heard his wife's voice urgently warning him, "Herman, I just heard on the news that there's a car going the wrong way on Route 280. Please be careful!" "It's not just one car", said Herman, "It's hundreds of them!"

e) [Cultural frame]+[utterance interpretation] jokes, which activate a cultural frame leading to an interpretation of some fragment that needs to be subsequently cancelled (YUS RAMOS, 2016, p. 132), as in the following case:

(10) One day a lawyer was riding in his limousine when he saw a guy eating grass. He told the driver to stop. He got out and asked him, "Why are you eating grass?" The man replied, "I'm so poor, I can't afford a thing to eat". So the lawyer said, "Poor guy, come back to my house". The guy then said, "But I have a wife and three kids". The lawyer told him to bring them along. When they were all in the car, the poor man said, "Thanks for taking us back to your house, it is so kind of you". The layer said, "You're going to love it there, the grass is a foot tall".

f) [Make-sense frame]+[cultural frame] jokes, which exploit the invalidation of frames belonging to these two categories that are initially activated and the search for alternatives for each of them (YUS RAMOS, 2016, p. 127-128), as in this example:

(11) A little girl and her dog are walking through the forest when they suddenly fall into a pit. They scramble and scramble but can't make their way out. The little girl yells, the dog barks, but no one is around to hear their calls for help. Slowly, the night sky turns black and they find themselves engulfed in utter darkness. Off in the distance, the wolves begin howling. Each howl is louder and closer than the last. The little girl holds the dog close to her chest and says sadly to the dog, "This is the worst mess in which ever have found ourselves, my darling Sparky". "Yeah", the dog says, "we're really screwed". "Sparky", the girl says, astonished, "I didn't know you could talk". "Well", the dog says, "I was kinda waiting for the right time to tell you".

g) [Make-sense frame]+[cultural frame]+[utterance interpretation] jokes, which rely on the first activation of specific make-sense and cultural frames, and the construction of a first interpretation, and the subsequent rejection of each of them in favour of alternative ones (YUS RAMOS, 2016, p.126-127). The following joke could illustrate this type:

(12) Three mice are sitting at a bar in a pretty rough neighborhood late at night trying to impress each other about how tough they are. The first mouse orders a scotch, gulps it down and slams the glass on the bar. He turns to the second mouse and says, "When I see a mousetrap, I lie on my back and set it off with my foot. When the bar comes down, I catch it in my teeth, bench press it 20 times to work up an appetite, and then make off with the cheese". The second mouse orders two shots of bourbon, slams them down and nearly breaks the glasses on the bar. He turns to the first mouse and replies, "Yeah, well, when I see rat poison, I collect as much as I can, take it home, grind it into a powder, and add it to my coffee each morning so I can get a good buzz going for the rest of the day". The first mouse and the second mouse then turn to the third mouse. The third mouse lets out a long sigh and says to the first two, "I don't have time for this bullshit. I gotta go home and screw the cat". 


\section{A structured methodological proposal}

Many scholars underline the necessity and importance of teaching L2 pragmatics, even if available evidence is not conclusive as to whether instruction of L2 pragmatic aspects has significant and/or lasting effects (KASPER, 1997; ALCÓN SOLER, 2005; ROSE, 2005). Although research shows that both explicit and implicit approaches -i.e., with provision or absence of metapragmatic information- may have benefits and drawbacks, explicit ones seem to yield more positive results (ROSE, 1997; KOIKE, PEARSON, 2005; MARTÍNEZ FLOR, FUKUYA, 2005; KONDO, 2008; NGUYEN, PHAM, PHAM, 2012). Despite the demands of appropriate pedagogical intervention in L2 pragmatics (ISHIHARA, 2010), it may be facilitative and improve learners' abilities, above all in FL contexts (KASPER, ROSE, 1993; SAFONT JORDÁ, 2005; ISHIHARA, COHEN, 2010), if it combines explicit and inductive techniques (JEON, TADAYOSHI, 2006; GLASER, 2013), or if input is enhanced (TAKAHASHI, 2001; MARTÍNEZ FLOR, FUKUYA, 2005).

Instructional proposals focusing on the L2 pragmatics abound, even if many of them centre exclusively on production of certain speech acts (e.g., HOLMES, BROWN, 1987; OLSHTAIN, COHEN, 1990, 1991; TAKAHASHI, BEEBE, 1993; BARDOVI-HARLIG, 1996; NELSON, EL BAKARY, AL BATAL, 1996; MARTÍNEZ FLOR, FUKUYA, 2005; PADILLA CRUZ, 2015b), discourse types (e.g., PADILLA CRUZ, 2013; ECONOMIDOU-KOGETSIDIS, 2015) or (im)politeness (BOU FRANCH, GARCÉS CONEJOS, 2003; MUGFORD, 2008), to name but a few. Some of them agree that learning must be a guided or structured process and integrate acquisitional strategies aimed at understanding how the target feature is produced by native speakers and debriefing its peculiarities, use strategies facilitating opportunities for real and/or simulated practice (COHEN, 2005; USÓ JUAN, MARTÍNEZ FLOR, 2008) and feedback on performance from both instructors and peers (ESLAMIRASEKH, 2005; KOIKE, PEARSON, 2005). Such a process may be organised into steps through which learners are introduced to the object of instruction, can observe it, reflect on it with a view to understanding it, and, finally, practise (KONDO, 2008; MARTÍNEZ FLOR, USÓ JUAN, 2006).

In the case of humour in general, and jokes in particular, proposals are scarce, perhaps because of the challenges that their production and interpretation pose to L2 learners (DENEIRE, 1995; BELL, 2017) and the fact that most efforts have mainly been dedicated to examining their use in the L2 class as a teaching device (COOK, 2000; MEDGYES, 2002; SMILEY, ANTÓN, 2012; SHARDAKOVA, 2013; ALDRICH, 2015; LOVORN, 2015; REDDINGTON, WARING, 2015; DERAKHSHAN, 2016). There are some noteworthy exceptions, though. One of them suggests taking advantage of humour in order to encourage L2 students to narrate joking stories that may help them notice cultural traits while communicating with each other in socially acceptable ways (DeFELICE, 2012). Aiming at improving learners' humour competence, another extant proposal relies on various theoretical frameworks and explicit instruction, and purports to cover diverse manifestations of humour, including puns, cartoons and distinct types of jokes (HODSON, 2014). Finally, two other proposals are concerned with translation, the first focusing on the (im)possibility of joketranslation (LAURIAN, 1992) and the second on translation as a vehicle to teach L2 sociocultural issues (VEGARA FABREGAT, 2018).

The proposal that follows, in contrast, does not seek to touch upon various manifestations of humour, nor does it focus on translation. Rather, it sets the spotlight on comprehension, so it has a cognitive orientation. Informed by the classification of jokes made by Yus Ramos (2016), its ultimate goal is to enhance ESL learners' awareness of the complexity of texts of this type by sensitising them to the linguistic, cultural and cognitive elements intervening in their construction and their potential combinations. Thus, it aims to foster their understanding, appraisal and reaction to these texts. It is intended for advanced students with a $\mathrm{C} 1$ or $\mathrm{C} 2$ level, using the terminology of the Common European Framework for Languages. Indeed, it is at this level that learners' lexical, syntactic, pragmatic and cultural competencies, as well as their reading and listening skills, are gaining, or have already achieved, considerable sophistication and may facilitate comprehension of crucial factors on which joking intent is heavily contingent, such as lexical and structural ambiguity, cultural information or commonsensical knowledge.

Additionally, the proposal that this paper puts forth partially follows the structure of another devised to teach verbal actions: namely, the so-called $6 R s$ approach (MARTÍNEZ FLOR, USÓ JUAN, 2006), which has also been adapted to teach phatic discourse (PADILLA CRUZ, 2013). However, the current proposal only includes five of its original six instructional phases or steps, which intend to make students research, reflect on jokes, receive information about them, reason about the factors of their hilariousness and revise their understanding 
thereof. This organisation allows for a progression from more general issues pertaining to jokes in the learners' L1 and exploration of their previous acquaintance with the factors in which their jocularity resides, to more specific ones connected with those in the target language. Moreover, the flexibility of this structure permits the allocation of particular thematic phases to actual sessions on the grounds of time availability, difficulties met by the students or their prowess. Through them, learners will gain valuable insights into the various kinds of jokes, where their comicality stems from, why some of them might fail to achieve the desired effects but, on the contrary, have negative outcomes, and possible cross-cultural differences between their L1 and L2. The five phases integrating this proposal are presented in detail in what follows.

\subsection{Step 1: Researching jokes}

Pedagogical intervention could start by making some sort of diagnostic assessment (BARDOVI-HARLIG et al., 1991) of learners' previous ideas about and reactions to joke-telling. They could be invited to remember jokes in their L1 and the situations where these were told. Then, specific examples could be elicited and shared with the class in order to create an adequate atmosphere (COOK, 2000; ALDRICH, 2015; DERAKHSHAN, 2016) and pave the way for an ensuing discussion. Since the aim of that discussion would be checking their attitudes to jokes, it could be guided by the teacher by means of awarenessraising questions about the actual situation where the jokes appeared, their topic(s) and spontaneity; whether they accompanied some action, disrupted a conversation, were followed by or enchained with other jokes; the audience's reactions and the teller's intentions when producing them. Examples of possible questions are gathered in the following worksheet:

\section{AWARENESS-RAISING QUESTIONS WORKSHEET}

(i) Do you remember where/in what situation the joke appeared? Do you remember who the interlocutors were?

(ii) What was the joke about?

(iii) Were the interlocutors doing something? Did that joke accompany a specific action?

(iv) Who told the joke? What do you think were their intention(s)?

(v) Did the joke interrupt the conversation or any action the interlocutors were doing?

(vi) What was the interlocutors' reaction to the joke? Did they understand it? Did they find it funny? If not, why?

(vii) Did you find it funny? Why or why not?

(viii) Do you think the joke achieved its goal?

The rationale for these questions is threefold. Firstly, detecting whether jokes triggered positive or expected reactions, like laughter, amusement or funniness, or, on the contrary, they were responded to negatively. If that was the case, the instructor could further ask what the unexpected responses were and what (might have) motivated them. Secondly, exploring the intentions that learners attributed to the teller(s) and whether they were actually fulfilled by the joke-telling. Thirdly, determining whether learners were conscious of other effects that the joke(s) had, like breaking the ice, softening a possible interactive conflict or mitigating some hazardous action. Moreover, through these questions learners would be implicitly introduced to the interactive functions that jokes may serve and the reactions that they may give rise to.

To conclude this phase, the instructor could similarly enquire if the students know any jokes in the L2, where they were told or heard it, and whether they found it humorous. If they can recall (a) joke(s), they could be encouraged to tell it aloud; if they did not, the teacher could provide a couple of relatively easy examples. In order to connect with the next phase, those examples could be of jokes belonging to the first type identified by Yus Ramos (2016), i.e., those in which a first seemingly plausible interpretation needs to be cancelled (1-6). 


\subsection{Step 2: Reflecting on jokes and humorousness}

Once jokes in general are introduced, it is time learners started to delve into how and why their intended humorous effects arise; or, in other words, where their comicality resides. This could be done through analysis of and reflection on the examples of jokes elicited or provided in the preceding phase. This task could be done individually, in pairs, in small groups or as a group, depending on factors such as group size and its idiosyncrasies.

If specific examples of jokes corresponding to any of the types differentiated by Yus Ramos (2016) were previously elicited, it could be interesting to discover if learners noticed the actual causes of their hilariousness by themselves. If not, the teacher could take advantage of the example(s) with which the preceding phase was closed and/or even expose learners to other jokes belonging to other types. This could be done through a printed handout, a projection on the screen or, if speed of delivery was not a problem, through audio or video recordings, even if these might be fairly difficult to find or prepare.

Two crucial issues would stand out at this stage. Firstly, teachers would need to ascertain whether learners detect that some jokes may solely exploit lexical or syntactic ambiguities, reference assignment, lexical adjustment, attribution of psychological states, cancelation of activated frames or rejection of some item of cultural information in favour of an alternative one, and, hence, those jokes would be relatively easy to understand (ARRÓNIZ PARRA, 2019). For instance, in a joke like (3) learners should spot the homophony between 'hares', the (more) salient sense of a phonological form therein because of the occurrence of the hyponym 'rabbits', with 'hairs', the less salient, but plausible, sense because of the appearance of the term 'head'. Secondly, teachers would need to check whether learners observe that other jokes may in contrast take advantage of more complex tactics to generate humour, as long as they may combine the parametres that humorists normally manipulate in various manners: [make-sense frame]+[utterance interpretation], [cultural frame]+[utterance interpretation], [make-sense frame]+[cultural frame] and [make-sense frame]+[cultural frame]+[utterance interpretation]. For this reason, the additional examples to which learners could be exposed should necessarily include some falling within types other than the first one distinguished by Yus Ramos (2016). All in all, focusing on the parametres intervening in joke-production is a first step to obtaining an appraisal of learners' awareness of the linguistic, cognitive and cultural factors triggering their desired or unexpected effects, as well as of their respective combinations.

Furthermore, if any of the examples of jokes provided by the students was reported to trigger unexpected responses, it would also be revealing to see why. If none of them did, the instructor could alternatively propose some examples of jokes liable to fail to achieve humorous reactions. Candidate jokes could be those dealing with certain sociocultural stereotypes, including characters of specific ethnicities or nationalities, or mentioning taboo topics like sex, sexual practices or sexual organs, as those in (13) or (14), respectively:

(13) Question: Why did the blonde take a ladder into the bar? Answer: She heard the drinks were on the house.

(14) There was this American tourist in Mexico, and he was getting tired of walking around, so he went up to a donkey rental place and said, "Can I rent a donkey?" The guy said, "We don't call them donkeys here; we call them asses. This is the only ass I have left, and you have to scratch him when you want to make him stop". The guy rides his ass for a while, sees a hotdog stand, and asks for a hotdog. The vendor replies, "We don't call them hotdogs here; we call the wieners". Meanwhile his donkey is wandering away, so he goes up to another tourist and says "Will you hold my wiener while I scratch my ass?"

Despite the play with the two possible senses of the expression 'to be on the house', the first joke includes a female character who is presented as unable to correctly interpret it because of alleged lack of intelligence. Therefore, students should be cautioned to the possibility that (blond female) members of an audience could take offence if the joke was told in front of them. In turn, the second one portrays an individual from a particular country with a peculiar accent and vocabulary. Despite the playful use of the ambiguous words 'ass' and 'wiener', and the absurdity of the situation that the joke depicts, learners should realise that those coming from the same country could feel besmirched if they thought that they are attributed willingness to engage in similar (absurd) actions or (nasty) practices, not to say that the situation in question could be found of bad taste. 
Finally, if any of the examples of jokes supplied by either the learners or the teacher was reported to not result in laughter or amusement, it would also be clarifying to unravel if that was due to structural factors -e.g., unfamiliar, unknown or complex vocabulary or syntax- lack of cultural information, impossibility to activate an appropriate make-sense frame or a combination of any of these three factors. If not, the instructor could likewise suggest some examples and discuss them. For instance, a joke like (15) could be explained to likely fail to cause humour if the audience lacked cultural information about the beliefs and practices of the members of the four churches in question and, in particular, of those of the Catholic church:

(15) There were four country churches in a small Texas town: The Presbyterian Church, the Baptist Church, the Methodist Church and the Catholic Church. Each church was overrun with pesky squirrels. One day, the Presbyterian Church called a meeting to decide what to do about the squirrels. After much prayer and consideration they determined that the squirrels were predestined to be there and they shouldn't interfere with God's divine will. In the Baptist Church the squirrels had taken up habitation in the baptistery. The deacons met and decided to put a cover on the baptistery and drown the squirrels in it. The squirrels escaped somehow and there were twice as many there the next week. The Methodist Church got together and decided that they were not in a position to harm any of God's creation. So, they humanely trapped the squirrels and set them free a few miles outside of town. Three days later, the squirrels were back. But the Catholic Church came up with the best and most effective solution. They baptized the squirrels and registered them as members of the church. Now they only see them on Christmas and Easter.

\subsection{Step 3: Receiving information about the factors intervening in joke-production}

After the initial exploration of learners' ideas about jokes and awareness of the factors responsible for their jocularity, teachers should provide systematised information about the latter. This obviously involves teacher-centred explicit instruction about pragmatic ambiguity, utterance interpretation and the roles played therein by cultural information and make-sense frames.

Dealing with pragmatic ambiguity requires explaining its origin(s). It should be clear to learners that its causes may be lexical phenomena such as polysemy, homophony or homonymy, which should be duly defined and exemplified in case they were not already acquainted with them or failed to remember them. It should also be stressed that ambiguity, regardless of its lexical nature, may also be a phrasal or syntactic phenomenon stemming from differing parsing or reading options. In any case, emphasis needs to be put on the impact of saliency as a consequence of the interpretative bias that the textual context of (many) jokes exerts, as well as on the unexpectedness and shocking and bewildering power of less likely senses and/or readings. Addressing utterance interpretation, in turn, involves accounting for the context-contingency of the series of parallel mental tasks carried out in the process. Learners should be conveniently informed about linguistic elements requiring assignment of reference or lexical adjustment, and the role played in comprehension by the attribution of intentions and psychological states to other individuals or the characters in a text. They also need to know that each of these tasks is performed on the basis of available and relatively easily-accessible contextual information, so that each of them might go wrong. Adequate comprehension of these notions and tasks could be ensured through the analysis of cases of lexical and structural ambiguity, as well as through exercises where learners would have to search for homophonous for specific words (e.g., 'hair', 'bear', 'flour', etc.), explain the potential senses of polysemous or homonymous items (e.g., 'bat', 'bank', 'bill', etc.), mention the possible readings of a set of ambivalent chunks or sentences (e.g., 'flying planes may be dangerous', 'to apply, push up bottom', etc.), determine the referents of certain referential expressions, delimit the denotation of a series of words figuratively used or attribute intentions, feelings and emotions to certain individuals in a context.

As for make-sense frames and cultural information, it is necessary that students be sensitised to what these are and why they are activated or accessed, and, more importantly, to their sense-endowing power and their likely variation in terms of content across individuals, time and cultural, gender, ethnic or geographical groups. Drawing their attention to this characteristic is particularly important with a view to accounting for the reasons why many 
jokes fail to achieve their intended effects, lose their appeal over time or across groups, or are offensive or disrespectful to some of them. As with the case of ambiguity and utterance interpretation, sensitisation to the role of make-sense frames could be complemented with exercises where learners name some familiar ones -e.g., the happily married couple, the hard-working person, the party night, etc.- and list frequent elements, events or states of affairs associated with them. In the case of cultural information, they could be invited to give examples of information that turns out essential to understanding certain phenomena or behaviours.

Such exercises could be followed by illustrations about how and why makesense frames should be shifted or already accessed cultural information needs to be rejected. After underlining the role of these three elements in the production and interpretation of jokes, and the fact that humorists often exploit them separately, in pairs or together, this phase could be wrapped up by announcing that their possible combinations result in seven categories of jokes which have been proved to match the humour-generating tactics followed by most of them (YUS RAMOS, 2013b). To conclude, the teacher could present and illustrate those combinations, or invite learners to guess what they are.

\subsection{Step 4: Reasoning about the types of jokes}

Imparting explicit information about the factors involved in joke-production and the seven differentiated types of jokes paves the way for students to analyse how specific examples of jokes work. By now, they would be equipped with the tools enabling them to reason about the construction of a variety of jokes, the specific parametre(s) responsible for their jocularity and why their humorous effects arise. This step would therefore be more practical, sample-oriented and learner-centred.

Learners could be invited to account for the specific factors contributing to the comicality of a list of jokes and to match them to each of the identified types thereof (YUS RAMOS, 2016). When so doing, they should also be able to provide the interpretation that they initially arrived at, explain the textual elements guiding them to it, describe the frame that they first activated or the cultural information that they initially relied on, if these were the cases. Next, they should spot the punchline introducing an incongruity and causing them to backtrack and reanalyse the text, and reconstruct the search for alternatives. The jokes in the list should be randomised, and the list itself could be printed out and handed to students so that they sort the jokes out individually or engage in collaborative work in pairs or in small groups. Alternatively, if their proficiency level was high enough, presentation of the jokes to be analysed could be done orally by the teacher or through audiovisual means.

As an alternative to that complex task -or as a complement, time permitting and provided that learners enjoyed it- the instructor could encourage learners to give examples of each type of joke. Then, they will either explain how their humorousness arises or ask peers to do so. This second task can be especially demanding, as learners might ignore jokes in the target language, not be familiar with enough of them, fail to remember their whole texts or be unable to accurately reproduce them.

\subsection{Step 5: Revision}

Prior to provision of feedback, Martínez Flor and Usó Juan's (2006) proposal includes a phase making learners practise by accomplishing the verbal action taught in various contexts. Since the current proposal is concerned with the factors enabling jokes to cause humor and their types, that phase would be unnecessary. Hence, pedagogical intervention should finally move to revising if learners have correctly classified the jokes proposed by the teacher, have succeeded at identifying the various sources of their funniness and have satisfactorily come up with appropriate first and second interpretations, make-sense frames and items of cultural information. This sort of assessment could be especially helpful to teachers, as they could determine the types of jokes posing (more) challenges to learners and/or gain invaluable information about those that they always or very frequently fail to understand or consider funny (ARRÓNIZ PARRA, 2019). In either case, discussion and qualitative analysis informed by introspection or think-aloud protocols would facilitate appraisal of their difficulties. 


\section{Conclusion}

Undoubtedly, joke-comprehension is an extremely complex and highly demanding process that very often challenges and puzzles L2 learners. Failure to interpret and reinterpret individual words or specific textual fragments, to access the appropriate information and/or to activate the necessary makesense frame(s) may prevent those learners from grasping the humorousness of jokes and being aware of what reaction is expected. It is therefore essential that they become aware of how humorists contrive these texts in order to trigger laughter and amusement. Indeed, L2 proficiency also depends on ability to successfully interpret and appraise them.

The methodological proposal that this paper has offered aims just this. In line with the original 6Rs approach, it is structured in various instructional phases, which allows for a logical organisation of content and facilitates its segmentation depending on time availability and learners' responses. Combining implicit and explicit instruction, as well as teacher- and student-centred activities, it sets the spotlight on the elements that humorists wield in joke-production. Obviously, a more encompassing proposal should include issues connected with joke-telling, but that is something that future works could address.

\section{References}

ALCÓN SOLER, Eva. Does instruction work for learning pragmatics in the EFL context? System, Linkoping, v. 33, n. 3, p. 417-435, 2005. https://doi.org/10.1016/i.system.2005.06.005

Aldrich, Simon. Teacher attitudes to humor in L2 English discussion classes. In: LESLEY, Jamie et al. (ed.). New directions in teaching and learning english discussion. Tokyo: Centre For English Discussion Class, 2015. v. 3, p. 225-234.

Apperly, Ian. Mindreaders: the cognitive basis of "theory of mind". London: Psychology Press, 2010. https://doi.org/10.4324/9780203833926

ARRÓNIZ PARRA, Santiago. Joke comprehension by Spanish B2 level learners of English. 2019. Dissertação (Mestrado em Linguistic, Literary and Cultural Studies) - Universidad de Sevilla, Sevilla, 2019.
ATTARDO, Salvatore. Semiotics and pragmatics of humor communication. Babel A.F.I.A.L., v. 1, p. 25-66, 2002. https://doi.org/10.1075/hop.9.hum2

ATTARDO, Salvatore; RASKIN, Victor. Script theory revis(it)ed: joke similarity and joke representation model. Humor: International Journal of Humor Research, Berlin, v. 4, n. 3-4, p. 293-348, 1991. https://doi.org/10.1515/humr.1991.4.3-4.293

BARDOVI-HARLIG, Kathleen. Pragmatics and language teaching: bringing pragmatics and pedagogy together. In: BOUTON, Lawrence F. (ed.). Pragmatics and language learning. Illinois: University of Illinois, 1996. (Monograph Series, v. 7). p. 21-39. https://doi.org/10.1111/.14679922.2012.00738.X

BARDOVI-HARLIG, Kathleen et al. Developing pragmatic awareness: closing the conversation. ELT Journal, London, v. 45, n. 1, p. 4-15, 1991. https://doi.org/10.1093/elt/45.1.4

BELL, Nancy D. Humor and second language development. In: ATTARDO, Salvatore (ed.) The Routledge handbook of language and humor. London: Routledge, 2017. p. 444-455. https://doi. org/10.4324/9781315731162-31

BELL, Nancy D.; ATTARDO, Salvatore. Failed humor: issues in non-native speakers' appreciation and understanding of humor. Intercultural Pragmatics, [s. l.], v. 7, n. 3, p. 423-44, 2010. https:// doi.org/10.1515/iprg.2010.019

BOU FRANCH, Patricia; GARCÉS CONEJOS, Pilar. Teaching linguistic politeness: a methodological proposal. International Review of Applied Linguistics in Language Teaching, Heidelberg, v. 41, n. 1, p. 1-22, 2003. https://doi.org/10.1515/iral.2003.001

Brown, Penelope; LEVINSON, Stephen C. Politeness: some universals in language usage. Cambridge: Cambridge University, 1987. https://doi.org/10.1525/ae.1988.15.4.02a00420

BUCARIA, Chiara. Lexical and syntactic ambiguity as a source of humor: the case of newspaper headlines. Humor: International Journal of Humor Research, Berlin, v. 17, n. 3, p. 279-309, 2004 https://doi.org/10.1515/humr.2004.013

COHEN, Andrew D. Strategies for learning and performing L2 speech acts. Intercultural Pragmatics, [s. l.], v. 2, n. 3, p. 275-301, 2005. https://doi.org/10.1515/iprg.2005.2.3.275

COOK, Guy. Language play, language learning. Oxford: Oxford University, 2000.

CURCÓ, Carmen. Some observations on the pragmatics of humorous interpretations: a relevance-theoretic approach. UCL Working Papers in Linguistics, London, v. 7, p. 27-47, 1995. 
CURCÓ, Carmen. The pragmatics of humorous interpretations: a relevance-theoretic Account. 1997. PhD Dissertation (PhD in Linguistics) - University College London, London, 1997.

DEFELICE, William. Using story jokes for real communication. English Teaching Forum, Washington, v. 50, n. 2, p. 43-44, 2012.

DENEIRE, Marc. Humor and foreign language teaching. Humor: International Journal of Humor Research, Berlin, v. 8, n. 3, p. 285-298, 1995. https://doi.org/10.1515/humr.1995.8.3.285

DERAKHSHAN, Kobra. Revitalizing language classes through humor. Procedia: Social and Behavioral Sciences, [s. l.], v. 232, n. 14, p. 18-23, 2016. https://doi.org/10.1016/j.sbspro.2016.10.005

DYNEL, Marta. Garden paths, red lights and crossroads: on finding our way to understanding the cognitive mechanisms underlying jokes. Israeli Journal of Humor Research, [s. l.], v. 1, n. 1, p. 6-28, 2012.

DYNEL, Marta. Joking aside: Sociopragmatic functions of conversational humour in interpersonal communication. In: CAP, Piotr; NIJAKOWSKA, Joanna (ed.). Current trends in pragmatics. Newcastle upon Tyne: Cambridge Scholars Publishing, 2007. p. 246-268.

DYNEL, Marta. There is method in the humorous speaker's madness: humour and Grice's model. Łodz Papers in Pragmatics, [s. l.], v. 4, n. 1, p. 159-185, 2008. https://doi.org/10.2478/ v10016-008-0011-5

ECONOMIDOU-KOGETSIDIS, Maria. Teaching email politeness in the EFL/ESL classroom. ELT Journal, London, v. 69, n. 4, p. 415-424, 2015. https://doi.org/10.1093/elt/ccv031

ESLAMI-RASEKH, Zohreh. Raising the pragmatic awareness of language learners. ELT Journal, London, v. 59, n. 3, p. 199-208, 2005. https://doi.org/10.1093/elt/ccio39

FORABOSCO, Giovannantonio. Is the concept of incongruity still a useful construct for the advancement of humor research? Łodz Papers in Pragmatics, [s. l.], v. 4, n. 1, p. 45-62, 2008. https://doi.org/10.2478/v10016-008-0003-5

GIORA, Rachel. On the priority of salient meanings: studies of literal and figurative language. Journal of Pragmatics, Amsterdam, v. 31, n. 7, p. 919-929, 1999. https://doi.org/10.1016/s03782166(98)00100-3

GLASER, Karen. The neglected combination: a case for explicit-inductive instruction in teaching pragmatics in ESL. TESL Canada Journal, [s. l.], v. 30, n. spe. 7, p. 150-163, 2013. https://doi. org/10.18806/tesl.v30i7.1158
HAY, Jennifer. Functions of humour in the conversations of men and women. Journal of Pragmatics, Amsterdam, v. 32, n. 6, p. 709-742, 2000. https://doi.org/10.1016/s0378-2166(99)00069-7

HODSON, Richard J. Teaching "humour competence". In: AISHAH, M. K. et al. (ed.). Proceedings of CLaSIC 2014: Knowledge, Skills and Competencies in Foreign Language Education. Singapore: NUS Centre for Language Studies, 2014. p. 149-161.

HOLMES, Janet; BROWN, Dorothy. Teachers and students learning about compliments. TESOL Quarterly, Washington, v. 21, n. 3, p. 523-546, 1987. https://doi.org/10.2307/3586501

HOUSE, Juliane. Cross-cultural pragmatic failure: from mistranslation to misunderstanding. In ARNTZ, Reiner; THOME, Gisela (ed.). Übersetzungswissenchaft: Ergebnisse und Perspectiven Festschrift für Wolfram Wilss. Tübingen: Narr, 1990. p. 315-325. https://doi.org/10.7202/002306ar

ISHIHARA, Noriko. Instructional pragmatics: bridging teaching, research, and teaching education. Language and Linguistic Compass, [s. l.], v. 4, n. 10, p. 938-953, 2010. https://doi. org/10.1111/j.1749-818x.2010.00242.X

ISHIHARA, Noriko; COHEN, Andrew D. Teaching and Learning Pragmatics: where language and culture meet. Harlow: Pearson Education, 2010. https://doi.org/10.1111/i.1540-4781.2012.01348.x

JEON, Eun J.; KAYA, Tadayoshi. Effects of L2 instruction on interlanguage pragmatic development In: MORRIS, John M.; ORTEGA, Lourdes (ed.). Synthesizing research on language learning and teaching. Amsterdam: John Benjamins, 2006. p. 165-208. https://doi.org/10.1075/lllt.13.10jeo

Jodłowiec, Maria. What makes jokes tick. UCL Working Papers in Linguistics, London, v. 3, p. 241-253, 1991.

KASPER, Gabriele. Can pragmatic competence be taught? Honolulu: University of Hawaii, Second Language Teaching \& Curriculum Center, 1997. (NetWork, n. 6). Disponível em: http:// www.nflrc.hawaii.edu/NetWorks/NWo6/. Acesso em: 5 nov. 2011

KASPER, Gabriele; ROSE, Kenneth R. Pragmatic development in a second language. Malden Blackwell, 2002.

KASPER, Gabriele; ROSE, Kenneth R. (ed.). Pragmatics in language teaching. Cambridge: Cambridge University, 1993.

KOIKE, Dale A.; PEARSON, Lynn. The effect of instruction and feedback in the development of pragmatic competence. System, Linkoping, v. 33, n. 3, p. 481-501, 2005. https://doi.org/10.1016/j. system.2005.06.008 
KONDO, Sachiko. Effects of pragmatic development through awareness-raising instruction: refusals by Japanese EFL learners. In: ALCÓN SOLER, Eva; MARTÍNEZ FLOR, Alicia (ed.). Investigating pragmatics in foreign language learning. Bristol: Multilingual Matters, 2008. p. 153-177. https://doi.org/10.21832/9781847690869-010

LAURIAN, Anne-Marie. Possible/impossible translation of jokes. Humor: International Journal of Humor Research, Berlin, v. 5, n 1-2, p. 111-127, 1992. https://doi.org/10.1515/humr.1992.5.1-2.111

LOVORN, Michael. Teachers' perceptions of humour as a classroom teaching, interaction, and management tool. European Journal of Humour Research, [s. l.], v. 3, n. 4, p. 24-35, 2015. https:// doi.org/10.7592/ejhr2015.3.4.lovorn

MARTÍNEZ FLOR, Alicia; FUKUYA, Yoshinori J. The effects of instruction on learners' production of appropriate and accurate suggestions. System, Linkoping, v. 33, n. 3, p. 463-480, 2005.

MARTÍNEZ FLOR, Alicia; USÓ JUAN, Esther. A comprehensive pedagogical framework to develop pragmatics in the foreign language classroom: the 6Rs approach. Applied Language Learning, [s. l.], v. 16, n. 2, p. 39-64, 2006. https://doi.org/10.1016/j.system.2005.06.007

MASCARO, Olivier; SPERBER, Dan. The moral, epistemic, and mindreading components of children's vigilance towards deception. Cognition, [s. l.], v. 112, n. 3, p. 367-380, 2009. https:// doi.org/10.1016/i.cognition.2009.05.012

Medgyes, Péter. Laughing matters: humour in the language classroom. Cambridge: Cambridge University, 2002.

MUGFORD, Gerrard. How rude! Teaching impoliteness in the second-language classroom. ELT Journal, London, v. 62, n. 4, p. 375-384, 2008. https://doi.org/10.1093/elt/ccmo66

NELSON, Gayle L.; EL BAKARY, Waguida; AL BATAL, Mahmoud. Egyptian and American compliments: focus on second language learners. In: GASS, Susan M.; NEU, Joyce (ed.). Speech acts across cultures. challenges to communication in a second language. Berlin: Mouton de Gruyter, 1996. p. 109-128. https://doi.org/10.1515/9783110219289.2.109

NGUYEN, Thi Thuy Minh; PHAM, Thi Hanh; PHAM, Minh Tam. The relative effects of explicit and implicit form-focused instruction on the development of L2 pragmatic competence. Journal of Pragmatics, Amsterdam, v. 44, n. 4, p. 416-434, 2012. https://doi.org/10.1016/j.pragma.2012.01.003

NORRICK, Neal R. A frame-theoretical analysis of verbal humor: bisociation as schema conflict. Semiotica, Berlin, v. 60, n. 3-4, p. 225-245, 1986. https://doi.org/10.1515/semi.1986.60.3-4.225

NORRICK, Neal R. Conversational joking: humor in everyday talk. Bloomington: Indiana University Press, 1993. https://doi.org/10.1017/s004740450001808x
NORRICK, Neal R. Humor in interaction. Language and Linguistics Compass, [s. l.], v. 4, n. 4, p. 232-244, 2010.

NORRICK, Neal R. Non-verbal humor and joke performance. Humor: International Journal of Humor Research, Berlin, v. 17, n. 4, p. 401-409, 2004. https://doi.org/10.1515/humr.2004.17.4.401 NORRICK, Neal R.; CHIARO, Delia (ed.). Humor in interaction. Amsterdam: John Benjamins, 2009.

NORRICK, Neal R.; SPITZ, Alice. Humor as a resource for mitigating conflict in interaction Journal of Pragmatics, Amsterdam, v. 40, n. 10, p. 1661-1686, 2008. https://doi.org/10.1016/j. pragma.2007.12.00

Olajoke, Akinkurolere S. Students' perception on the use of humor in teaching English as a second language in Nigeria. International Educational Research, [s. l.], v. 1, n. 2, p. 65-73, 2013.

OLSHTAIN, Elite; COHEN, Andrew D. Teaching speech act behaviour to non-native speakers In: CELCE-MURCIA, Marianne (ed.). Teaching English as a second or foreign language. New York: Newbury House, 1991. p. 154-165.

Olshtain, Elite; COHEN, Andrew D. The learning of complex speech act behaviour. TESL Canada Journal, [s. l.], v. 7, n. 2, p. 45-65, 1990. https://doi.org/10.18806/tesl.v7i2.568

PADILLA CRUZ, Manuel. An integrative proposal to teach the pragmatics of phatic communion in ESL classes. Intercultural Pragmatics, [s. l.], v. 10, n. 1, p. 131-160, 2013. https://doi.org/10.1515/ ip-2013-0005

PADILLA CRUZ, Manuel. Epistemic vigilance, cautious optimism and sophisticated understanding Research in Language, [s. l.], v. 10, n. 4, p. 365-386, 2012. https://doi.org/10.2478/v10015-011-0040-y

PADILLA CRUZ, Manuel. Fostering EF/SL learners' pragmatic awareness of complaints and their interactive effects. Language Awareness, Clevedon, v. 24, n. 2, p. 123-137, 2015b. https:// doi.org/10.1080/09658416.2014.996159

PADILLA CRUZ, Manuel. Interlocutors-related and hearer-specific causes of misunderstanding processing strategy, confirmation bias and weak vigilance. Research in Language, [s. l.], v. 15, n. 1, p. 11-36, 2017. https://doi.org/10.1515/rela-2017-0006

PADILLA CRUZ, Manuel. On the role of vigilance in the interpretation of puns. Humor International Journal of Humor Research, Berlin, v. 28, n. 3, p. 469-490, 2015 a.

PADILLA CRUZ, Manuel. Pragmatic failure, epistemic injustice and epistemic vigilance. Language \& Communication, Oxford, v. 39, p. 34-50, 2014. https://doi.org/10.1016/i.langcom.2014.08.002 
PADILLA CRUZ, Manuel. Vigilance mechanisms in interpretation: hermeneutical vigilance. Studia Linguistica Universitatis Iagellonicae Cracoviensis, [s. l.], v. 133, n. 1, p. 21-29, 2016 https:// doi.org/10.2478/v10148-011-0012-6.

POMERANTZ, Anne; BELL, Nancy D. Humor as safe house in the foreign language classroom. The Modern Language Journal, Madison, v. 95, p. 148-161, 2011. https://doi.org/10.1111/j.15404781.2011.01274.X

POWELL, J. P.; ANDRESEN, L. W. Humour and teaching in higher education. Studies in Higher Education, Dorchester on Thames, v. 10, n. 1, p. 79-90, 1985. https://doi.org/10.1080/0307507 8512331378726

RASKIN, Victor. Semantic mechanisms of humor. Dordrecht: Reidel, 1985

REDDINGTON, Elizabeth; WARING, Hansun Z. Understanding the sequential resources for doing humor in the language classroom. Humor: International Journal of Humor Research, Berlin, v. 28, n. 1, p. 1-24, 2015. https://doi.org/10.1515/humor-2014-0144

RITCHIE, Graeme. Reinterpretation and viewpoints. Humor: International Journal of Humor Research, Berlin, v. 9, n. 3, p. 251-270, 2006. https://doi.org/10.1515/HUMOR.2006.014

RITCHIE, Graeme. The linguistic analysis of jokes. Abingdon: Routledge, 2004. https://doi. org/10.4324/9780203406953

ROSE, Kenneth R. On the effects of instruction in second language pragmatics. System, Linkoping, v. 33, n. 3, p. 385-399, 2005. https://doi.org/10.1016/j.system.2005.06.003

ROSE, Kenneth R. Pragmatics in the classroom: theoretical concerns and practical possibilities. In: BOUTON, Lawrence F. (ed.). Pragmatics and language learning 8. Urbana: University of Illinois, 1997. p. 267-295.

SAFONT JORDÁ, María Pilar. Third language learners: pragmatic production and awareness. Clevedon: Multilingual Matters, 2005.

SHARDAKOVA, Maria. "I joke you don't": second language humor and intercultural identity construction. In: KINGINGER, Celeste (ed.). Social and cultural aspects of language learning in study abroad. Amsterdam: John Benjamins, 2013. p. 207-237. https://doi.org/10.1075/lltt.37.09sha

SHARWOOD-SMITH, Michael. Consciousness-raising and the second language learner. Applied Linguistics, Oxford, v. 2, n. 2, p. 159-168, 1981. https://doi.org/10.1093/applin/2.2.159
SLUGOSKI, Ben R.; TURNBULL, William. Cruel to be kind and kind to be cruel: sarcasm, banter and social relations. Journal of Language and Social Psychology, Cleveland, v. 7, n. 2, p. 101-121, 1988. https://doi.org/10.1177/0261927x8800700202

SMILEY, Jennifer R.; ANTÓN, Marta. Teachers' roles and mediating strategies of learners engagement in the L2 classroom. In: YOON, Bogun; KIM, Hoe K. (ed.). Teachers' roles in second language learning: classroom applications of sociocultural theory. Charlotte: Information Age Publishing, 2012. p. 231-248.

SOLSKA, Agnieszka. Relevance-theoretic comprehension procedure and processing multiple meanings in paradigmatic puns. In: Wałaszewska, Ewa; PISKORSKA, Agnieszka (ed.). Relevance theory: more than understanding. New Castle upon Tyne: Cambridge Scholars Publishing, 2012a. p. 167-182.

SOLSKA, Agnieszka. The relevance-based model of context in processing puns. Research in Language, [s. l.], v. 10, n. 4, p. 387-404, 2012b. https://doi.org/10.2478/v10015-012-0001-0

SPERBER, Dan. Understanding verbal understanding. In: KHALFA, Jean (ed.). What is intelligence? Cambridge: Cambridge University, 1994. p. 179-198.

SPERBER, Dan et al. Epistemic vigilance. Mind and Language, Oxford, v. 25, n. 4, p. 359-393, 2010

SULS, Jerry. Cognitive and disparagement theories of humour: a theoretical and empirical synthesis. In: CHAPMAN, Antony J.; FOOT, HUGH C. (ed.). It's a funny thing, humour. Oxford: Pergamon, 1977. p. 41-45. https://doi.org/10.1016/b978-0-08-021376-7.50012-7

SULS, Jerry. Cognitive processes in humor appreciation. In: MCGHEE, Paul E.; GOLDSTEIN Jeffrey H. (ed.). Handbook of humor research. New York: Springer-Verlag, 1983. (Basic Issues, v. 1). p. 39-57. https://doi.org/10.1007/978-1-4612-5572-7 3

SZIRMAI, Monika. Raising multicultural awareness by teaching humour in foreign language classes. In: ALAO, George et al. (ed.). Didactique plurilingue et pluriculturelle: l'acteur en contexte modialisé. Paris: Éditions des Archives Contemporaines, 2012. p. 193-202. https:// doi.org/10.3726/978-3-0352-0266-3

TAKAHASHI, Satomi. The role of input enhancement in developing pragmatic competence. In: KASPER, Gabriele; ROSE, Kenneth R. (ed.). Pragmatics in language teaching. Cambridge: Cambridge University, 2001. p. 171-1990. https://doi.org/10.1017/cbo9781139524797.014

TAKAHASHI, Tomoko; BEEBE, Leslie M. Cross-linguistic influence in the speech act of correction. In: KASPER, Gabriele; BLUM-KULKA, Shoshana (ed.). Interlanguage pragmatics. New York: Oxford University, 1993. p. 138-158. https://doi.org/10.1017/s0047404500018649 
THOMAS, Jenny. Cross-cultural pragmatic failure. Applied Linguistics, Oxford, v. 4, n. 2, p. 91$112,1983$.

USÓ JUAN, Esther; MARTÍNEZ FLOR, Alicia. Teaching learners to appropriately mitigate requests. ELT Journal, London, v. 62, n. 4, p. 349-357, 2008. https://doi.org/10.1093/elt/ccm092

VEGARA FABREGAT, Laura. La traducción del humor como herramienta pedagógica en el aula de L2. Enseñanza \& Teaching, [s. l.], v. 36, n. 2, p. 91-104, 2018. https://doi.org/10.14201/ et201836291104

YUS RAMOS, Francisco. A relevance-theoretic classification of jokes. Łodz Papers in Pragmatics, [s. l.], v. 4, n. 1, p. 131-157, 2008. https://doi.org/10.2478/v10016-008-0004-4

YUS RAMOS, Francisco. An inference-centered analysis of jokes: the intersecting circles model of humorous communication. In: RUIZ GURILLO, Leonor; ALVARADO, Belén (ed.). Irony and humor: from pragmatics to discourse. Amsterdam: John Benjamins, 2013a. p. 59-82. https:// doi.org/10.1075/pbns.231.05yus

YUS RAMOS, Francisco. Analyzing jokes with the intersecting circle model of humorous communication. Łodz Papers in Pragmatics, [s. l.], v. 9, n. 1, p. 3-24, 2013b. https://doi.org/10.1515/ lpp-2013-0002

YUS RAMOS, Francisco. Humour and relevance. Amsterdam: John Benjamins, 2016.

YUS RAMOS, Francisco. Humor and the search for relevance. Journal of Pragmatics, Amsterdam, v. 35, n. 9, p. 1295-1331, 2003. https://doi.org/10.1016/s0378-2166(02)00179-0

ZIYAEEMEHR, Ali; KUMAR, Vijay; ABDULLAH, Mohd S. F. Use and non-use of humor in academic ESL classrooms. English Language Teaching, London, v. 4, n. 3, p. 111-119, 2011. https://doi org/10.5539/elt.v4n3p111 